\title{
The duration of pregnancy in ecologically-challenged area. The effects of environmental pollution with aromatic hydrocarbons on the angiogenesis and elements of the mesenchymal tissue of the human placenta
}

\author{
Waldemar Wierzba ${ }^{1}$, Stanisław Radowicki², Iwona Bojar ${ }^{3}$, Jarosław Pinkas ${ }^{4}$ \\ ${ }^{1}$ University of Humanities and Economics in Łódź, UHE Satellite Campus in Warsaw, Poland \\ ${ }^{2}$ Department of Gynecological Endocrinology, Medical University of Warsaw, Warsaw, Poland \\ ${ }^{3}$ Institute of Rural Medicine in Lublin, Lublin, Poland \\ ${ }^{4}$ Center of Postgraduate Medical Education, Warsaw, Poland
}

\begin{abstract}
Introduction: The literature presents only few reports regarding the effects of elevated levels of aromatic hydrocarbons (AH) on the functions of the human placenta. The effects of environmental contamination with AH (including phenol and 1-hydroxypyrene) have certain negative effects on parenchymal organs such as human placenta.

Objective: The paper aimed to assess the effects of elevated levels of $\mathrm{AH}$ on the placental angiogenesis and elements of the mesenchymal tissue of the placenta.

Material and methods: Tissue material from 50 afterbirths from Płock constituted a study group, whereas 50 afterbirths from Kutno constituted a control group. Immunohistochemical reactions with the peroxidase method using LSAB kits (DAKO) were performed. The extent and intensity of reactions were analysed. The levels of phenols and 1-hydroxypyrene in the excreted urine of pregnant women (undergoing delivery) were detected using gas chromatography and colorimetry.

Results: The levels of phenol and 1-hydroxypyrene in the excreted urine were demonstrated to be statistically significantly higher in patients living in the area of Płock. Statistically significantly higher expression of antibodies indicating placental angiogenesis was observed in the placentas in the Płock group $(p<0.01)$. Moreover, lower expression of vimentin indicating reactions with proteins in mesenchymal cells was observed in the Kutno group $(p<0.01)$.

Conclusions: Pregnancy in the environment with elevated levels of aromatic hydrocarbons has detrimental effects on the human placenta. The foetus is protected by activation of adaptation and compensation mechanisms that are manifested as significant angiogenesis and greater development and differentiation of mesenchymal cells compared to the control group. Key words: human placenta, aromatic hydrocarbons, angiogenesis, mesenchymal tissue
\end{abstract}

Ginekologia Polska 2017; 88, 4: 180-184

\section{INTRODUCTION}

Human placenta has two major roles: it is an organ responsible for transfer of metabolites and it is a place where hormones and enzymes necessary for a growing foetus are produced or metabolised. For the foetus, it functions as lungs, gastrointestinal tract, kidneys and the whole system of endocrine glands, including liver [1, 2]. Placenta's own metabolism is extremely active. Its individual components, especially their functional performance, indicate foetal well-being. With regard to earlier studies the trophoblastic epithelium seems to be the most active component of the afterbirth [3]. The placental connective tissue of the mesenchymal origin is a component that so far has been poorly studied. Results of few papers indicate it regulates placental functioning [4]. 
Aromatic hydrocarbons, especially phenol, are highly toxic to numerous cellular structures such as parenchymal organs (liver, lungs, placenta) and haematopoietic system [5-7]. Liebhart and Pawiński observed damage to the trophoblastic epithelium, its increased remodelling and renewal in human placentas as well as delayed and reduced steroidogenesis in human placentas from the area of Płock due to exposure to petrochemical industry in women with high urine excretion of phenol [8].

The placental barrier separating the maternal circulation from the foetal circulation reduces availability of chemical substances to the foetus to a relatively low extent.

As the levels of aromatic hydrocarbons in the air in the area around refineries and petrochemical plants are significantly higher it results in dangerous chronic intoxication that have an asymptomatic course and therefore only after some time is it possible to observe numerous injuries to organs and tissues.

Significantly elevated (significantly higher) levels of phenols and 1-hydroxypyrene in the excreted urine are biological markers of intoxication [9-11].

The effects of contamination with aromatic hydrocarbons on parenchymal organs may be assessed by studying and comparing afterbirths from normal pregnancies in the environment with increased phenol levels and afterbirths from the areas without contamination with such substances.

\section{OBJECTIVES}

The paper aims to assess the effects of elevated levels of aromatic hydrocarbons ( $\mathrm{AH}$ ) excreted in the urine on the placental angiogenesis and the quality of elements of the mesenchymal tissue of the placenta.

\section{MATERIAL AND METHODS}

The study material was collected from patients with a negative medical history whose pregnancies were in the environment exposed to elevated levels of aromatic hydrocarbons ( $\mathrm{AH}$ ) in the air (study group - Płock) and patients from the environment without $\mathrm{AH}$ contamination (control group - Kutno). A precondition for enrolling afterbirth into the study was uncomplicated physiological full-term pregnancy (39-41 week). All observed pregnancies completed in a spontaneous labour and healthy children were born (Apgar score of 10). Prior to pregnancy patients had not been suffering from any chronic diseases, were not smokers and did not abuse alcohol or drugs. Patients in the control and study group did not differ significantly with regard to the age, parity and body weight. Children born as a result of these pregnancies did not differ statistically with regard to their birth weight. During pregnancy and delivery each patient had urine phenol levels assessed three times in order to obtain information on the total exposure to hydrocarbons as their urine metabolites are simple phenols. Phenol levels were assessed using three methods: HPLC (liquid chromatography), GC (gas chromatography) and a colorimetric method with 4-aminoantipyrine. Additionally, the urine levels of 1-hydroxypyrene were determined with gas chromatography as it is a biological marker of exposure to polycyclic aromatic hydrocarbons.

Tissue material from 50 afterbirths from Płock constituted a study group, whereas 50 afterbirths from Kutno constituted a control group. In all cases two specimens were collected from the umbilical cord, one from the extraplacental foetal membranes and two or three specimens from the placenta itself. All specimens obtained were processed in order to obtain paraffin-embedded blocks. Paraffin-embedded blocks were used to obtain slides for routine histopathological evaluation and then the most representative placental slides were selected for further immunohistochemical tests. Histopathological evaluation was performed after routine staining with hematoxylin and eosin. Preliminary results did not show significant histopathological differences in both groups of placentas, namely the study group from Płock and the control group from Kutno.

Then, immunohistochemical reactions in selected slides from 50 evaluated afterbirths from the area with environmental contamination (Płock) and also in slides from 50 afterbirths from the control group (Kutno area) were performed. Results obtained - intensity and extent of immunohistochemical reactions - were used as a basis to conduct a comparatory analysis of expression of various reaction products.

Immunohistochemical reactions were performed with the peroxidase method using LSAB kits (HRP Rabbit/Mouse — Universal LSAB 2 Kits by DAKO, Denmark). They are based on sequential use of biotinylated antibody cross-linkers labelled with streptavidin, with horseradish peroxidase. This method is extremely sensitive and low levels of primary antibodies can be detected.

Immunohistochemical reactions with the following antibodies were performed:

- indicating placental angiogenesis: Rb a Ulex Europaeus Lectin type 1 (UEA-1), indicating vascular endothelium; this reaction is indicated in order to assess vascularisation (placental angiogenesis) in the studied placentas;

- indicating mesenchymal elements of the placental tissue: Mo a Hu Vimentin, that indicates reactions with protein in cells of the mesenchymal origin such as endothelial cells, connective tissue cells, smooth muscle cells and lymphoid cells.

Reactions were assessed with two methods. Firstly, they were assessed using an arbitrary 4-point scale: 0, 1, 2, 3, where $0=$ no reaction, 3 = strong, even reaction.

Additionally, immunohistochemical reactions performed were assessed with regard to their extent and 
intensity using the computer system for morphometric assessment, namely Cell Soft Imaging System by Olympus; and it was possible by combining a light microscope with a digital camera (Olympus BX41, Olympus C3040) with a computer. Results of immunohistochemical tests were made more objective thanks to such an assessment. Differences were considered to be statistically significant at the significance level of $95 \%(p<0.05)$.

Results obtained were subject to a statistical analysis with the PQStat v. 1.6.1 Software. T-student and $x^{2}$ tests of independence were used.

\section{RESULTS}

The levels of phenol and 1-hydroxypyrene in the excreted urine were statistically significantly higher in patients living in the area of Płock compared to patients from Kutno (Tab. 1). Dimensions of placentas from the Płock group were greater, on average, from the ones in the Kutno group but this difference was not statistically significant.
The analysis of placental angiogenesis evaluated based on the placental vascularisation indicated by labelling of vascular endothelium ( $\mathrm{Rb}$ a Ulex Europaeus Lectin type 1 ULEA-1 antibodies) showed statistically higher activity and scope of colour-producing immunohistochemical reactions in the studied placentas in the Płock group $(p<0.01)$ (Tables 2 and 3 ).

The analysis of mesenchymal elements of the placental tissue was possible thanks to labelling reactions with protein in cells of the mesenchymal origin (endothelial cells, connective tissue cells, smooth muscle cells and lymphoid cells). Mo a Hu Vimentin antibodies were used in the analysis. The analysis was performed as described in Tables 2 and 3. These tables are not located in the text, due to the transparency of the publication.

Calculations revealed also a significantly higher intensity and scope of the reactions of Vimentin antibody $(p<0.01)$ in cells collected from the study group (Płock) as compared to the control group (Kutno).

Table 1. The urine levels of excreted phenol and 1-hydroxypyrene in pregnant women

\begin{tabular}{|c|c|c|c|c|}
\hline Study groups & $\begin{array}{l}\text { Phenol met. Hplc [mg/L] } \\
\qquad(X \pm S D)\end{array}$ & $\begin{array}{l}\text { Phenol met. Gc } \\
{[\mathrm{mg} / \mathrm{L}](X \pm \mathrm{SD})}\end{array}$ & $\begin{array}{c}\text { Phenol met. } \\
\text { z 4-aminoantypiryną } \\
\text { [mg/L] }(X \pm S D)\end{array}$ & 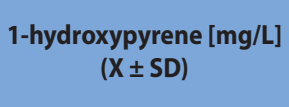 \\
\hline $\begin{array}{l}\text { Kutno } \\
n=50\end{array}$ & $2.025 \pm 0.767$ & $2.044 \pm 0.754$ & $5.059 \pm 0.788$ & $0.225 \pm 0.169$ \\
\hline $\begin{array}{l}\text { Płock } \\
n=50\end{array}$ & $4.419 \pm 2.484$ & $4.455 \pm 2.624$ & $8.735 \pm 2.835$ & $0.519 \pm 0.366$ \\
\hline $\begin{array}{l}\text { T-student test for } \\
\text { independent samples }\end{array}$ & $\begin{array}{c}t=6.5115 \\
k=98 \\
p<0.001\end{array}$ & $\begin{array}{c}t=6.2443 \\
k=98 \\
p<0.001\end{array}$ & $\begin{array}{c}t=8.8337 \\
k=98 \\
p<0.001\end{array}$ & $\begin{array}{c}t=5.156831 \\
k=98 \\
p<0.001\end{array}$ \\
\hline
\end{tabular}

$\mathrm{X}$ - average value; SD — standard deviation

Table 2. Intensity of colour-producing reactions to label vascular endothelium in the trophoblast

\begin{tabular}{|l|c|c|c|}
\hline \multirow{2}{*}{ Groups } & \multicolumn{3}{|c}{ The intensity of the reaction } \\
\cline { 2 - 4 } & No reaction & Trace reaction & Poor reaction \\
\hline Study group $(n=50)$ & $1(2 \%)$ & $14(28 \%)$ & $23(46 \%)$ \\
\hline Control group $(n=50)$ & $1(2 \%)$ & $28(56 \%)$ & $18(36 \%)$ \\
\hline$X^{2}$ test of independence & & $X^{2}$ statistics $=10.676 ;$ degrees of freedom $=3 ; p=0.013$
\end{tabular}

Table 3. Scope of colour-producing reactions to label vascular endothelium in the trophoblast

\begin{tabular}{|c|c|c|c|}
\hline \multirow{2}{*}{ Groups } & \multirow{2}{*}{ Number (n) } & \multicolumn{2}{|c|}{ Average area $(X \pm S D)$} \\
\hline & & {$\left[\mu \mathrm{m}^{2}\right]$} & (\%) \\
\hline Study group (Płock) & 50 & $4040.70 \pm 2601.02$ & $2.81 \pm 1.80$ \\
\hline Control group (Kutno) & 50 & $2315.23 \pm 2019.19$ & $1.61 \pm 1.40$ \\
\hline \multicolumn{2}{|c|}{ T-student test for independent samples } & $\begin{array}{c}t=3.705 \\
k=98 \\
p<0.001\end{array}$ & $\begin{array}{c}t=3.721 \\
k=98 \\
p<0.001\end{array}$ \\
\hline
\end{tabular}

$\mathrm{X}$ - average value; SD — standard deviation 


\section{DISCUSSION}

The study material showed that the urine levels of excreted phenol (measured with three methods) and 1-hydroxypyrene in pregnant women in the Płock area were statistically significantly higher compared to pregnant women from the Kutno area. The Płock petrochemical plant (now PKN Orlen) emits more than 100.000 tonnes of gas substances into the atmosphere, including sulphur and nitrogen compounds, as well as aromatic hydrocarbons that are benzene derivatives such as hydroxypyrene, benzopyrene and phenol, among others (based on annual GUS [Central Statistical Office] reports).

It means that the Płock area is contaminated with chemical substances from the industry mentioned above, and this contamination mainly includes significant levels of hydrocarbons, and additionally, all tested pregnant women were significantly affected by these substances. Phenol and 1-hydroxypyrene are scientifically considered to be biological markers of exposure to polycyclic aromatic hydrocarbons $[10,11]$. Phenol is the main metabolite of decomposition of aromatic hydrocarbons in the human body. Papers by other authors confirm high urine levels of phenol in pregnant women living in the areas contaminated by refinery and petrochemical plants [12-15]. Papers quoted showed a correlation between high levels of excreted phenol with abnormal manifestation of the afterbirth. Analyses of macroscopic, microscopic and histochemical changes were performed by such scientists as Liebhart, Pawiński, Radowicki and Wierzba in the 1970s, 1980s and 1990s. These studies demonstrated changes in the morphology and metabolism of afterbirths from full-term pregnancies such as microinfarctions, excessive fibrin deposition or reduced activity of placental enzymes in the villous trophoblast [16-19].

In this paper authors decided to use modern immunohistochemical methods to determine whether there are changes (differences) at the level of expression of products of reactions of antigens indicating individual placental functions in afterbirths from normal pregnancies.

The study material was collected from patients with a negative medical history whose pregnancies were in the environment exposed to elevated levels of aromatic hydrocarbons $(\mathrm{AH})$ in the air (study group - Płock) and patients from the environment without $\mathrm{AH}$ contamination (control group - Kutno). A precondition for enrolling afterbirth into the study was uncomplicated physiological full-term pregnancy (39-41 week). All observed pregnancies completed in a spontaneous labour and healthy children were born (Apgar score of 10). Prior to pregnancy patients had not been suffering from any chronic diseases, were not smokers and did not abuse alcohol or drugs. Patients in the control and study group did not differ significantly with regard to the age, parity and body weight. Children born as a result of these pregnancies did not differ statistically with regard to their birth weight. It means that the biological quality of children born in both cities is similar.

In order to do that a patient group was selected so as the only "pathology" was elevated concentration of phenol and 1-hydroxypyrene in the excreted urine, and there were no other differences between studied groups.

The study showed significantly higher activity and scope of colour-producing immunohistochemical reactions of placental angiogenesis (evaluated based on the placental vascularisation) in the placentas from the Płock group. It indicates increased compensation and adaptation mechanisms as a response to environmental pollution with derivatives of aromatic hydrocarbons in the group from Płock. Wierzba and Radowicki observed significantly higher levels of neutral polysaccharides (P.A.S. stain), acid mucopolysaccharides and collagen fibres (van Gieson's stain) in the villous stroma what indicated changed metabolism of the connective tissue in placentas from the Płock group [20, 21]. Moreover, Radowicki observed numerous calcium deposits on the maternal surface of placentas as evidence for increased metabolism [22]. Presence of collagen fibres (and other proteins) in cells of the mesenchymal origin (mesenchyme is the embryonic connective tissue that differentiates into all types of tissues) confirmed by a reaction with vimentin was statistically significantly higher in the study group. Liebhart observed deposition of significant levels of neutral polysaccharides as evidence for increased activity of adaptation and compensation mechanisms in the contaminated environment $[4,23]$. Neutral polysaccharides are present when immune reactions are intensified and antigen-antibody complexes are accumulated as a body response to environmental pollution [24]. In several studies morphometric analyses showed impaired capillary vasculature in placental villi with high urine phenol excretion. It is a significant change with regard to the placental functioning. At the same time it was observed that underdevelopment of capillaries is compensated by their excessive sinusoidal remodelling so as the surface of the maternal-foetal exchange is not reduced significantly, therefore it does not affect the foetal development [4, 25]. Increased activity of placental angiogenesis plays a significant role in this process as it is responsible for compensatory remodelling of capillaries in terminal and stromal villi that has been shown in this study.

Undoubtedly, it is evidence for active protection of the foetus under conditions of environmental contamination with aromatic hydrocarbons.

\section{CONCLUSIONS}

Pregnancy in the environment with elevated levels of aromatic hydrocarbons has detrimental effects on the human placenta. The foetus is protected by activation of 
adaptation and compensation mechanisms that are manifested as active angiogenesis and formation of new blood vessels that provide proper nutrition and oxygen supply to the foetus and significantly greater development of mesenchymal cells compared to the control group.

\section{REFERENCES}

1. Fox H, Sebire NJ. Pathology of the placenta. Saunders Elsevier, Philadelphia 2007

2. Perrin E. Pathology of the placenta. Churchil Livingstone, New York 1984.

3. Wierzba WM, Radowicki S. Histochemical characteristics of placenta in women from an ecologically threatened environment (Płock). Ginekol Pol. 1997; 68(3): 118-122, indexed in Pubmed: 9480228.

4. Liebhart M, Rembiszewska et al. Badania histologiczne i histochemiczne popłodu z wczesnych okresów ciąży u kobiet pracujących w środowiskowych warunkach zakładów rafineryjnych. Sprawozdanie z umowy Nr 23 z MZRiP, 1978.

5. McConnell EE. Enviromental Health Criteria 150. Benzen. World Health Organization, Geneva 1993.

6. Van Es. Enviromental Health Criteria 170. Tetrabromobisphenol. World Health Organization, Geneva 1995.

7. Pawlicki L, Smoczyński S, Jaworski J. Chlorowane węglowodory we krwi położnic z rejonu Olsztyna. Problemy Lekarskie. 1982; 21(2): 229-237.

8. Liebhart M, Roszczynska G, Pawiński R, et al. Badania mikroskopowe popłodu z ciąży donoszonej z uwzględnieniem zmian toksykologicznych stwierdzonych u matki. Gin Pol. 1982; 53(4): 221-227.

9. Boogaard PJ, van Sittert NJ. Exposure to polycyclic aromatic hydrocarbons in petrochemical industries by measurement of urinary 1-hydroxypyrene. Occup Environ Med. 1994; 51(4): 250-258, indexed in Pubmed: 8199667.

10. Brzeźnicki S, Jakubowski M. Jedno-hydroksypiren jako biologiczny marker narażenia na wielopierścieniowe węglowodory aromatyczne. Instytut Medycyny Pracy, Łódź 1995.

11. Lis E, Garlej T. Test fenolowy w moczu jako wykładnik narażenia na węglowodory aromatyczne. Medycyna Pracy. 1978; 29(1): 53-58.

12. Yang $\mathrm{CY}$, Cheng BH, Hsu TY, et al. Association between petrochemical air pollution and adverse pregnancy outcomes in Taiwan. Arch Environ Health. 2002; 57(5): 461-465, doi: 10.1080/00039890209601438, indexed in Pubmed: 12641190
13. Xu X, Cho Sl, Sammel M, et al. Association of petrochemical exposure with spontaneous abortion. Occup Environ Med. 1998; 55(1): 31-36, indexed in Pubmed: 9536160.

14. Schönfelder G, Wittfoht W, Hopp H, et al. Parent bisphenol A accumulation in the human maternal-fetal-placental unit. Environ Health Perspect. 2002; 110(11): A703-A707, indexed in Pubmed: 12417499.

15. Pelkonen O, Saarni H. Unusual patterns of benzo[a]pyrene metabolites and DNA-benzo[a]pyrene adducts produced by human placental microsomes in vitro. Chem Biol Interact. 1980; 30(3): 287-296, indexed in Pubmed: 7379208.

16. Radowicki S, Wierzba WM. Dehydrogenase 3-beta-hydroxysteroid activity in placentas from physiologically pregnant women from an ecologically threatened area (Płock). Ginekol Pol. 1997; 68(3): 123-126, indexed in Pubmed: 9480229.

17. Chen $\mathrm{D}, \mathrm{Cho} \mathrm{SI}$, Chen $\mathrm{C}$, et al. Exposure to benzene, occupational stress, and reduced birth weight. Occup Environ Med. 2000; 57(10): 661-667, indexed in Pubmed: 10984337.

18. Lösch A, Kainz C. Immunohistochemistry in the diagnosis of the gestational trophoblastic disease. Acta Obstet Gynecol Scand. 1996; 75(8): 753-756, indexed in Pubmed: 8906012.

19. Zamorska L. Aktywność enzymów utleniających i morfologia łożysk ludzkich z ciąż donoszonych. Folia Medica Cracoviensia. 1982/1983; 24: 67-87.

20. Wierzba W, Radowicki S, Pawiński R. Microscopic evaluation of the placenta from women in an ecologically threatened area (Płock). Part I. Ginekol Pol. 1997; 68(3): 109-113, indexed in Pubmed: 9480226.

21. Wierzba W, Radowicki S. Microscopic evaluation of the placenta from women in an ecologically threatened area (Płock), part II. Gin Pol. 1997; 68(3): 114-117.

22. Radowicki S. Porównanie przebiegu ciąży na terenie miast - Kutna i Płocka. TNP, AM Warszawa, UW Płock, Warszawa-Płock 1992

23. Liebhart $M$, et al. Badania mikroskopowe popłodu z ciąży donoszonej z uwzględnieniem zmian toksykologicznych stwierdzonych u matki. Gin Pol. 1982; 53(4): 221-227.

24. Radowicki S, Wierzba WM. Multiple aspects of placenta from ecologically-challenged area (Plock). Ginekol Pol. 1997; 68(2): 59-63, indexed in Pubmed: 9498997.

25. Lin CM, Li CY, Mao IF. Increased risks of term low-birth-weight infants in a petrochemical industrial city with high air pollution levels. Arch Environ Health. 2004; 59(12): 663-668, doi: 10.1080/00039890409602951, indexed in Pubmed: 16789475. 